\title{
PSYCHIATRIC CLIENT EMBRACEMENT ON PRIMARY HEALTH CARE
}

\section{ACOLHIMENTO DO CLIENTE PSIQUIÁTRICO NA ATENÇÃO PRIMÁRIA À SAÚDE}

\section{Jaciara Aparecida de Jesus SILVA ${ }^{1}$; Lúcia Aparecida FERREIRA ${ }^{2}$; Fernanda Bonato ZUFFI ${ }^{3}$; Ricardo Jader CARDOSO ${ }^{4}$; Marina Pereira REZENDE ${ }^{5}$; Guilherme Silva MENDONÇA ${ }^{6}$; Emerson Piantino DIAS ${ }^{7}$}

1. Nurse Graduated from the undergraduate course in Nursing of Federal University of Triângulo. Multi residing in adult health from the Federal University of Triângulo, Graduated student in General ICU and Emergency Departament; 2. Ph.D in Nursing - Professor at the Federal University of Triângulo Mineiro, Uberaba, MG, Brazil; 3. Master Professor in Nursing - Professor at the Federal University of Triângulo Mineiro, Uberaba, MG, Brazil; 4. Ph.D in Nursing - Professor at the Federal University of Triângulo Mineiro, Uberaba, MG, Brazil; 5. Ph.D. in Nursing - Professor at the Federal University of Triângulo Mineiro, Uberaba, MG, Brazil; 6. Pedagogue, Nurse, Specialist Distance Education, Uberlândia, MG, Brazil, guilhermesilva@ famed.ufu.br; 7. Master in Health Promotion from the University of Franca, Professor at the Federal University of Uberlândia, Uberlândia, MG, Brazil.

\begin{abstract}
This study aims to meet the professionals interviewed, identify the way nurses work facing the client with psychological distress and their knowledge on the concept of mental health and mental illness. This is a descriptive study, with a qualitative approach. The sample consisted of 26 nurses of the Family Health Strategy - FHS. According to Minayo, four categories emerged from data analysis: Embracement, Absence of actions for social reintegration, Orientation, Meanings. There is no differentiation between embracement and actions for social reintegration. Family approach is done through guidance. The concept of mental health has been defined as well-being, and mental illness, the presence of diseases and/or disorders.
\end{abstract}

KEYWORDS: Mental Health. Psychiatric Nursing. Primary Health Care.

\section{INTRODUCTION}

Psychiatric reform and National Policy for Mental Health Care (NPMHC) have been modifying the concept and practice of mental health care. Deinstitutionalization is the main purpose of the reform, as well as NPMHC seeks to reduce beds in psychiatric hospitals expanded to the extra-hospital network. In 2001, the General Coordination of Mental Health (CGSM) has developed guidelines for the articulation between Mental Health and Primary Health Care, such as the prioritization of mental health in the family health teams, follow-up actions of mental health and mental health matrix support, the ESF (TANAKA, 2009; SOUSA, 2007). The Family Health Program (FHP), afterwards the Family Health Strategy (FHS) began in Brazil in 1991 with the purpose of reorganizing health care, causing professionals to humanize the service and develop actions of prevention and restoration of health, fully and continuously (SOUSA, 2007).

Partnership between FHS and mental health is extremely important, but the professionals who make up this team are not yet familiar with the psychic suffering (DELFINI, 2009). The main idea is that the professionals are trained technically and have abilities to develop partnerships in order to send to the Psychosocial Attention Centers (CAPS) only customers who require more specialized attention. The reference and counter-reference are fundamental in this new form of assistance (JUCÁ, 2009).

Thus, mental health deserves an innovative and holistic look. For that this study aimed to evaluate the professionals interviewed, identify the form of work of nurses towards customer with psychological distress and a knowledge of them on the concept of mental health and mental illness.

\section{MATERIALS AND METHODS}

This is a qualitative study, with the aim of uncovering the psychiatric client embracement in Primary Health Care. The sample consisted of nurses and nurses of the Family Health Strategy (FHS) from the urban area of the city of UberabaMG, during January 2012. It was used as a criterion in this study: be a male ESF nurse and accept to participate in the research.

Participation in the interview was preceded by clarification on the goal and the signature of the informed consent (TFCC). To maintain the confidentiality of the subjects it was used the letter E followed by the corresponding number in the interview. The project was approved by the Research Ethics Committee of the Federal University of Triângulo Mineiro-UFTM, under the opinion paragraph CEP/1999 UFTM. Collection occurred in the workplace, being used an instrument consisting of two parts. The first part related to socio-demographic data (name, age, sex and years 
of experience). The second one consisted of the guiding questions: How is the embracement of the psychiatric client carried out? Which actions are developed for social reintegration of psychiatric client in the community? What is the approach made with the families of these psychiatric clients? What is mental health and mental illness for you?

Uberaba municipality consists of 46 family health teams in the urban area, being our sample of 26 nurses. Two teams did not have any nurses, four were on maternity leave, six were on vacation and eight refused to participate in the research. From the 26 nurses, only 10 agreed to have the interview recorded. The other ones preferred to fill in the data collection instrument in the presence of the researcher. For data analysis it was performed the thematic analysis proposed by Minayo (2004), which consists of three steps: pre-analysis and exploration of the material, processing of results and interpretation (MINAYO, 2004). From the categorization of data five categories emerged: embracement, professional training, lack of actions for social reintegration, orientation and meanings.

\section{RESULTS AND DICUSSION}

Firstly, we highlight the socio-demographic profile of the sample studied. Of the 26 nurses interviewed it was noted that: $24(92.3 \%)$ were female and $2(7.7 \%)$, male. Related to the age group $10(38.4 \%)$ were between 20 to 29 years, 11 $(42.3 \%)$ between 30 to 39 years, $4(15.3 \%)$ between 40 and 49 years and $1(3.8 \%)$ did not answer. As for the time of graduation $7(26.9 \%)$ are younger than 4 years, $16(61.5 \%) 5$ to 9 years, $1(3.8 \%) 10$ to 14 years and $2(7.6 \%) 15$ to 20 years.

\section{Category: Embracement}

The embracement category includes lines for demonstrating how this is accomplished by the Family Health Strategy (FHS), being attention the same for the whole community, namely: listening, nursing consultation and referrals:

There is no embracement directed only to psychiatric client (E11).

[...] His embracement is the same way as it is done with other people [...] (E22).

(E26). [...] welcomes him as if it were an ordinary patient [...] (E26).

[...] where we listen to this patient needs and welcome him [...] (E18).

[...] We perform a nursing consultation [...] (E21).

[...] we see what is his complaint and gives him proper guiding [...] (E9).
Embracing requires one of the most difficult human senses, hearing; knowing how to listen is not always easy. And the psychiatric client requires even more skills to the embracement, because in some cases he/she is agitated, confused and aggressive. Embracement goes beyond a cordial reception, involves an active listening, bond, efficaciousness and professional performance. However, for embracement and humanization implementation it is necessary that the nurse review his/her worker process in health units (LIMA, 2007). Embracement can offer an approach not only with mental health, but with other health areas that remain lost in the community.

\section{Category: Absence of actions for social reintegration}

This category considers the testimony of 13 nurses who reported the absence of actions for social reintegration of the psychiatric client in the community.

None (E2).

None, via FHS (E3).

We do not have specific actions for social reintegration of the psychiatric patient in the Community (E6).

There are no actions targeted at this audience in particular, there is work for the whole community (E11).

Actually, we do not have specific actions [...] (E 20).

Psychosocial rehabilitation requires three vertices to happen: home, leisure and work. It is not a process from which it is expected the individual to reach normality, but rather an acceptable level of social interaction (JORGE, 2006). It is noticed that the psychiatric reform brings not only a change in the hospitalocentric paradigm, but on psychosocial rehabilitation, reinserting the person with mental disorder in their daily activities, making possible family and social interaction (MIELKE, 2009), which agrees with the study of Jorge (2006) pointing to psychosocial rehabilitation as an overcoming of traditional health paradigm / mental illness and that a lot has to be done to overcome the political and institutional barriers still exist in the culture of most professionals hindering social reintegration (JORGE, 2006).

\section{Category: Guidance}

The category guidance was observed in the report of ten nurses during the interview and encompasses the approach made by them with the families of psychiatric clients. 
Psychiatric client embracement...

Guidelines are accomplished (E2).

They are oriented on the diagnosis and treatment and the importance of the family role [...] (E5).

Guidance on pathology, medications, reactions, help on how to stand themselves in front of certain manifestations (E15). Approach - information / guidance, integral and humanized assistance (E16).

Support to family needs, with patient and guidance to continue the treatment (E17).

Psychiatric client's family is exposed to high stress load, especially the person who is responsible for the care. Groups are a way of providing assistance to families. The idea of treating families in group therapy appeared in the New York State Hospital in 1950. The goal was that families could learn with experience exchanges, through dialogue and support relationships. In many cases problem begins at home, being necessary for the family to be treated just like the patient (PONCIANO, 2010). Recognizing the overload experienced by family allows health care professional setting strategies of care (AZEVEDO, 2011). However, it is necessary to redraft concepts, rethinking old attitudes that excluded the patient with mental disorder and his family. Health increasingly needs professionals who know how to listen, assess, plan and intervene with families (WAIDMAN, 2005).

\section{Category: Meanings}

When inquiring nurses about what mental health and mental illness is the answer was that mental health to a large part is welfare, and mental illness is related to those people who are affected by any disease and/or disorder.

Having mental health is being well in all aspects, physical, mental, social, economical [...] Mental illness are disorders caused by inheritance [...] (E 3). Mental health: It is the human psychic wellbeing [...] Mental illness: It is when the subject has some type of mental disorder (E5).

Mental health, I think it is the well-being [...] Mental illness - that patient who has
SILVA, J. A. J. et al.

mental suffering, who has some pathology

[...] (E9).

Mental Health - physical and emotional wellbeing. Mental illness - diseases and health hazard of

psychic/emotional/neurological condition (E16).

According to Gonçalvez (2001), mental health involves the human being as a whole, biological, psychic, social and spiritual. Mental illness is a failure in behavior, feelings and thoughts. A different person, that is, who does not live within the rules of society and cannot develop certain functions (GONÇALVEZ, 2001).

For that reason, it is necessary that universities review their teaching and learning methodologies when discussing about Psychiatry and that students have opportunity for work in three levels of attention, family health teams, specialized and hospital care.

Embracement to the person with psychic suffering is difficult, because there is no differentiation among other customer cares, and this difficulty may be related to lack of professional training and even the academic qualification. Also, the absence of actions for social reintegration of the customer in distress and the approach of the families only through guidance. Mental health concept has been defined as well-being, and mental illness, the presence of diseases and/or disorders, although we know that there are other concepts that are worth mentioning on the theme in question developed in this study.

It is clear to understand fundamental concepts for the application of assistance in practice, which are often linked to cultural training these professionals have obtained during undergraduate study, and also, the stigma to the person with mental distress is very present. With the concern facing complexity, another aspect that deserves our attention is the implementation of a training program for nurses from Family Health Strategy in mental health, because, this way we will reach the components that impact on assistance, such as social reintegration, family support and embracement facility.

RESUMO: Este estudo tem como objetivo conhecer os profissionais entrevistados, identificar a forma de trabalho dos enfermeiros frente ao cliente com sofrimento psíquico e o conhecimento dos mesmos sobre o conceito de saúde mental e doença mental. Trata-se de um estudo descritivo, com abordagem qualitativa. Amostra de 26 enfermeiros da ESF. Análise dos dados segundo Minayo emergiram quatro categorias: Acolhimento, Ausência de ações para reinserção social, Orientação, Significados. Não há diferenciação no acolhimento e ações para a reinserção social. Abordagem das 
famílias é feita através de orientação. O conceito de saúde mental foi definido como bem-estar, e de doença mental a presença de patologias e/ou transtornos.

PALAVRAS-CHAVE: Saúde Mental. Enfermagem Psiquiátrica. Atenção Primária à Saúde.

\section{REFERENCES}

AZEVEDO, D. M.; MIRANDA, F. A. N. A representação social de familiares nos centros de atenção psicossocial. Esc Anna Nery, Rio de Janeiro, v. 15, n. 2, p. 354-360. 2011.

DELFINI, P. S. S.; SATO, M. T.; ANTONELI, P. P.; GUIMARÃES, P. O. S. Parceria entre CAPS e PSF: o desafio da construção de um novo saber. Ciên. Saúde Coletiva, Rio de Janeiro, v. 14, n. 1, p. 1483-1492. 2009.

GONCALVEZ, A. M.; SENA, R. R. A Reforma Psiquiátrica no Brasil: contextualização e reflexos sobre o cuidado com o doente mental na família. Rev. Latino-Am. Enfermagem, Ribeirão Preto, v. 9, n. 2, p. 48-55. 2001. http://dx.doi.org/10.1590/S0104-11692001000200007

JORGE, M. S. B.; RANDEMARK, N. F. R.; QUEIROZ, M. V. O.; RUIZ, E. M. Reabilitação Psicossocial: visão da equipe de Saúde Mental. Rev Bras Enferm,, Brasília, v. 59, n. 6, p.734-9. 2006. http://dx.doi.org/10.1590/S0034-71672006000600003

JUCÁ, V. J. S.; NUNES, M. O.; BARRETO, S. G. Programa de saúde da família e saúde mental: impasses e desafios na construção da rede. Ciên. Saúde Coletiva, Rio de Janeiro, v. 14, n. 1, p. 173-182. 2009.

LIMA, M. A. D. S.; RAMOS, D. D.; ROSA, R. B.; NAUDERER, T. M.; DAVIS, R. Acesso e acolhimento em unidades de saúde na visão dos usuários. Acta Paul Enferm,, São Paulo, v. 20, n. 1, p. 12-17. 2007. http://dx.doi.org/10.1590/S0103-21002007000100003

MIELKE, F. B.; KANTORSKI, L. P.; JARDIM, V. M. R.; OLSCHOWSKY, A.; MACHADO, M. S. O cuidado em saúde mental no CAPS no entendimento dos profissionais. Ciên. Saúde Coletiva, Rio de Janeiro, v. 14 , n. 1 , p. $159-164.2009$.

MINAYO, M. C. S. O desafio do conhecimento: pesquisa qualitativa em saúde. São Paulo: Hucitec, 7ist ed., 2004.

PONCIANO, E. L. T.; CAVALCANTI, M. T.; CARNEIRO, T. F. Observando os grupos multifamiliares em uma instituição psiquiátrica. Rev Psiq Clin, São Paulo, v. 37, n. 2, p. 43-7. 2010.

http://dx.doi.org/10.1590/S0101-60832010000200002

SOUSA, M. E.; MATIAS, G. N.; GOMES, K. F. A.; PARENTE, A. C. M. Atenção em Saúde Mental. Secretaria de Estado de Saúde de Minas Gerais. Belo Horizonte, 2ist ed., 2007.

TANAKA, O. Y.; RIBEIRO, E. L. Ações de saúde mental na atenção básica: caminho para ampliação da integralidade da atenção. Ciên. Saúde Coletiva, Rio de Janeiro, v. 14, n. 2, p. 477-486. 2009.

WAIDMAN, M. A. P.; ELSEN, I. O cuidado interdisciplinar à família do portador de transtorno mental no paradigma da desinstitucionalização. Texto Contexto-Enferm., Florianópolis, v. 14, n. 3, p. 341-9. 2005. 